\title{
Manajemen Strategik: Pemikiran Michael Porter dan Implikasinya bagi Pengembangan Ekonomi Kreatif
}

\author{
Nuryadi WIJIHARJONO \\ Universitas Muhammadiyah Prof. Dr. Hamka (UHAMKA) \\ Email: nuryadiwijiharjono@yahoo.com
}

\begin{abstract}
Beginning from the strategic thinking of Michael Porter, the purpose of this paper is to present implications for the development of competitive advantage in the creative economy in the global context. According to Porter, there are five competitive forces that determine industry strength: (1) potential new entrants; (2) suppliers; (3) buyers; (4) substitute product; and (5) competitors in industry. That is, how the company's leadership understands the five things will determine what strategy should be chosen. Survey evidence shows that the development of the creative economy is an evolution that directs economic growth.
\end{abstract}

Keywords: industry structure; strategic positioning; value chain; competitive advantage; and creative economy.

\begin{abstract}
Abstrak
Berangkat dari pemikiran manajemen strategik Michael Porter, tujuan tulisan ini adalah untuk mengemukakan implikasi bagi pengembangan keunggulan kompetitif ekonomi kreatif dalam konteks persaingan global. Menurut Porter, terdapat lima kekuatan kompetitif yang menentukan kekuatan industri: (1) Pemain baru potensial; (2) Pemasok; (3) Pembeli; (4) Substitusi; dan (5) Pesaing dalam industri. Artinya, bagaimana pimpinan perusahaan memahami mengenai kelima hal tersebut akan menentukan strategi apa yang harus dipilih.

Berdasarkan pengujian model yang dilakukan oleh Pott dan Cunningham, menunjukkan bahwa: (1) industri kreatif merupakan sektor khusus yang berpengaruh dalam perkembangan ekonomi; (2) industri kreatif merupakan bagian dari sistem inovasi. Menurutnya, perkembangan relatif dari industri kreatif bukan satu keganjilan, tapi akan membuka teori sistem ekonomi. Sebagaimana pertumbuhan ekonomi akibat dari adanya
\end{abstract}


kemajuan teknologi, Bukti survei menunjukkan bahwa perkembangan industri kreatif merupakan evolusi yang mengarahkan kemajuan perekonomian nasional.

Kerangka pemikiran Porter telah digunakan dalam pengembangan keunggulan kompetitif pada industri kreatif, sebagaimana terjadi di Amerika Serikat, Inggris, Belanda, dan China. Melalui pengklasteran industri (cluster industries), industri tersebut menjadi berkembang dan mampu memengaruhi perekonomian global. Dan, Indonesia dengan generasi kreatif milinealnya, memiliki potensi besar untuk dapat berkembang, sebagaimana industri kreatif di banyak negara maju.

Kata kunci: struktur industri; strategic positioning; value chain; competitive advantage; dan ekonomi kreatif.

\section{Pengantar}

Pada tahun 1998, konsep industri kreatif, dan sekarang menjadi ekonomi kreatif, untuk pertama kalinya diperkenalkan oleh pemerintah Inggris (DCMS, 1998). Sepuluh tahun kemudian, pemerintah Indonesia baru memulai memetakan dan mencanangkan sektor ini pada tahun 2008 (Kementerian Perdagangan RI, 2008). Padahal di beberapa negara maju, dalam kurun waktu tersebut, pengembangan sektor kreatif ini, bukan hanya dilihat sebagai entitas bisnis dan ekonomi, tetapi juga sebagai elemen penting dalam pembangunan wilayah dan perkotaan (Bagwell, 2008). Bahkan, sebagaimana termuat pada situs resmi universitas, industri kreatif juga telah menjadi kajian serius di beberapa perguruan tinggi kelas dunia.

Dengan mendasarkan pada pemikiran stratejik Michael Porter, tujuan tulisan ini adalah untuk mengemukakan implikasi bagi pengembangan keunggulan kompetitif ekonomi kreatif dalam konteks persaingan global. Sebab, menurut Porter, peran pemerintah berpengaruh kuat dalam menciptakan keunggulan kompetitif nasional suatu industri (Porter, 1991). Oleh karena itu, untuk mencapai tujuan tersebut sistematika penulisan ini adalah: Pertama, akan dikemukakan terlebih dulu riwayat singkat untuk memperkaya dalam memahami pemikiran seorang manusia. Kedua, memaparkan pokokpokok pemikiran stratejik Porter. Ketiga, menjelaskan pengertian industri kreatif. Keempat, mengemukakan beberapa hasil penelitian atau kajian empirik tentang 
pengembangan ekonomi kreatif. Kelima, berdasarkan bagian sebelumnya, kemudian penulis akan menarik implikasi pemikiran stratejik Porter bagi pengembangan industri kreatif. Keenam adalah kesimpulan.

\section{Riwayat Singkat Porter}

Berbeda dengan artikel jurnal tradisional, di sini penulis kemukakan riwayat sigkat seorang Michael Eugene Porter. Ia adalah seorang akademisi dari Harvard Business School (HBS) yang dikenal keahliannya di bidang ekonomi dan strategi bisnis. Ia lahir di Ann Arbor, Michigan, USA, tanggal 23 Mei 1947, putra dari seorang insinyur (civil engineer). Menamatkan kuliah di Universitas Prenceton (BSE) dan Universitas Harvard (MBA, PhD). Karena kecerdasannya ketika belajar di HBS, Porter mengundang perhatian dari dosennya, yakni Prof Chistensen (1952-2020).

Latar belakang dari keluarga terpelajar dan mengenal dunia industri, memperkaya kemampuan Porter dalam menganalisis industri dan bisnis. Banyak buku dan artkel jurnal yang ia tulis, baik secara sendiri maupun bersama koleganya, termasuk buah karyanya yang terkenal, di antranya adalah Strategi Bersaing (Competitive Strategy) maupun Keunggulan Bersaing (Competitive Advantage). Sampai saat ini, di usianya yang sudah senja, tulisannya di bidang bisnis dan ekonomi masih paling sering dicitasi, terutama bagi mereka yang sedang belajar stategi bisnis maupun manajemen strategi.

\section{Karya Tulis Michael Porter}

Menyandang profesor dan terlibat dalam kegiatan sosial filantropi, bukan berarti tanpa kritik. Tidak sedikit akademisi yang mengkritik pemikirannya. Misalnya dinilai kurang konsisten dalam berteori dan kurangnya dukungan data empirik. Berikut adalah daftar karya Michael Porter. ${ }^{1}$

1. Porter, M.E. (1979) "How Competitive Forces Shape Strategy", Harvard Business Review, March/April 1979.

\footnotetext{
${ }^{1}$ https://en.wikipedia.org/wiki/Michael_Porter, diakses tanggal 13 Juni 2021. PkI. 18.26 WIB.
} 
2. Porter, M.E. (1980) Competitive Strategy, Free Press, New York, 1980. The book was voted the ninth most influential management book of the 20th century in a poll of the Fellows of the Academy of Management. ${ }^{[19]}$

3. Porter, M.E. (1985) Competitive Advantage, Free Press, New York, 1985.

4. Porter, M.E. (ed.) (1986) Competition in Global Industries, Harvard Business School Press, Boston, 1986.

5. Porter, M.E. (1987) "From Competitive Advantage to Corporate Strategy", Harvard Business Review, May/June 1987, pp 43-59.

6. Porter, M.E. (1996) "What is Strategy", Harvard Business Review, Nov/Dec 1996.

7. Porter, (2017) "Michael Porter on Creating Competitive Advantage for Yourself", HBR Ascend

8. Porter, M.E. (1998) On Competition, Boston: Harvard Business School, 1998.

9. Porter, M.E. (1990, 1998) The Competitive Advantage of Nations, Free Press, New York, 1990.

10. Porter, M.E. (1991) "Towards a Dynamic Theory of Strategy", Strategic Management Journal, 12 (Winter Special Issue), pp. 95117. http://onlinelibrary.wiley.com/doi/10.1002/smj.4250121008/abstract

11. McGahan, A.M. \& Porter, M.E. Porter. (1997) "How Much Does Industry Matter, Really?" Strategic Management Journal, 18 (Summer Special Issue), pp. 1530. http://onlinelibrary.wiley.com/doi/10.1002/(SICI)10970266(199707)18:1\%2B\%3C15::AID-SMJ916\%3E3.0.CO;2-1/abstract

12. Porter, M.E. (2001) "Strategy and the Internet", Harvard Business Review, March 2001, pp. 62-78.

13. Porter, M.E. \& Kramer, M.R. (2006) "Strategy and Society: The Link Between Competitive Advantage and Corporate Social Responsibility", Harvard Business Review, December 2069, pp. 78-92.

14. Porter, M.E. (2008) "The Five Competitive Forces That Shape Strategy", Harvard Business Review, January 2008, pp. 79-93.

15. Porter, M.E. \& Kramer, M.R. (2011) "Creating Shared Value", Harvard Business Review, Jan/Feb 2011, Vol. 89 Issue 1/2, pp 62-77 
16. Porter, M.E. \& Heppelmann, J.E. (2014) "How Smart, Connected Products are Transforming Competition", Harvard Business Review, November 2014, pp 6588

17. Porter, M.E. \& Heppelmann, J.E. (2015) "How Smart, Connected Products are Transforming Companies", Harvard Business Review, October 2015, pp 97-114

18. Porter, M.E. \& Heppelmann, J.E. (2017) "Why Every Organization Needs an Augmented Reality Strategy", Harvard Business Review, November 2017, pp $46-62$

19. Gehl, K.M. \& Porter, M.E. (2017) "Why Competition in the Politics Industry is Failing America", Harvard Business School, September 2017.

20. Porter, M.E. \& Teisberg, E.O. (2006) "Redefining Health Care: Creating ValueBased Competition On Results", Harvard Business School Press, 2006.

21. Berwick, DM, Jain SH, and Porter ME. "Clinical Registries: The Opportunity For The Nation." Health Affairs Blogs, May 2011.

22. Jain SH, Weintraub R, Rhatigan J, Porter ME, Kim JY. "Delivering Global Health". Student British Medical Journal 2008; 16:27.

23. Kim JY, Rhatigan J, Jain SH, Weintraub R, Porter ME. "From a declaration of values to the creation of value in global health: a report from Harvard University's Global Health Delivery Project". Global Public Health. 2010 Mar; 5(2):181-8.

24. Rhatigan, Joseph, Sachin H Jain, Joia S. Mukherjee, and Michael E. Porter. "Applying the Care Delivery Value Chain: HIV/AIDS Care in Resource Poor Settings." Harvard Business School Working Paper, No. 09-093, February 2009.

\section{Pemikiran Stratejik Porter}

Basis unit analisis sebuah teori strategi, menurut Porter (1991), harus secara strategis memperjelas atau mempertegas tujuan akhir dari bisnis atau industri. Perusahaan dapat membagi sumber daya, aktivitas, dan keterampilan lintas bisnis yang berbeda. Nilai kompetitif tindakan dapat diukur melalui produk atau pelayanan kepada para pembeli. Pendekatan ini merupakan strategi pada level perusahaan. Kesuksesan perusahaan bergantung pada kekuatan yang dimiliki dan posisi relatif di dalam industri tersebut. Aktivitas internal macam mana serta aset apa yang mereka miliki. Untuk itu, 
menurut Porter (1991), paling tidak terdapat empat masalah penting yang harus dijelaskan.

1. Sebuah teori (strategi) harus secara simultan mampu menjelaskan keterkaitan antara perusahaan pada dirinya dengan lingkungan yang lebih luas di mana ia beroperasi. Sebab, kendala dan pengaruh lingkungan berhubungan dengan outcomes.

2. Sebuah teori (strategi) harus memungkinkan tindakan secara terpusat terhadap perubahan eksogen di berbagai bidang, seperti kebutuhan pembeli, teknologi dan pasar input. Pilihan strategi adalah seri permainan yang berubah. Contoh kasus, sebuah produk dapat sukses memimpin pasar dalam suatu waktu, tetapi gagal di lain waktu.

3. Sebuah teori (strategi) harus menyediakan ruang kepada perusahaan untuk tidak hanya memilih di antara pilihan yang jelas, melainkan juga untuk membuat sesuatu yang baru. Dengan kata lain, terbuka terhadap kreativitas dan inovasi untuk melahirkan strategi alternatif.

4. Terakhir, persoalan sejarah keberuntungan yang mempengaruhi outcomes kompetitif. Beberapa ahli ekonomi sering menyederhanakan persoalan bahwa hal tersebut merupakan pilihan strategi yang baik. Atau, merefleksikannya lebih jauh sebagai aspek-aspek lingkungan yang tidak dapat diukur. Poin pentinya adalah, bahwa keberuntungan berpengaruh penting terhadap bagaimana mengembangkan sebuah teori strategi.

Dalam artikelnya What is Strategy? Porter mengemukakan bahwa perusahaan harus mengubah strateginya jika perubahan struktural terjadi pada industri tersebut. Menurutnya, operasional perusahaan yang efektif bukanlah merupakan strategi. Positioning adalah strategi dalam menghadapi perubahan lingkungan bisnis. Strategi positioning berarti menciptakan posisi daya saing yang unik sehingga perusahaan memiliki posisi baru untuk mendapatkan trade-offs baru dan keunggulan yang 
berkelanjutan (Porter, 1996). Jadi, pemikiran stratejik, dalam pandangan Porter, adalah bagaimana menjadikan perusahaan memiliki posisi yang unik dalam persaingan.

Mengikuti Hunt (1972), Porter menjelaskan bahwa industri dapat dikelompokan menjadi cluster, dan hal tersebut merupakan strategi yang akan memudahkan pengembangan industri tersebut. Di beberapa negara maju, strategi ini telah dipilih oleh pemerintah dalam mengembangkan kekuatan industrinya (1979). Untuk menjelaskan kesuksesan kompetitif perusahaan, kita membutuhkan sebuah teori strategi yang berhubungan dengan perubahan lingkungan dan perilaku perusahaan untuk mencapai outcomes pasar. Untuk itu, Porter mengemukakan hasil penelitiannya dan menyarankan pentingnya rantai kausalitas.

Bagaimana kita menjelaskan pilihan strategi yang bagus? Salah satu pandangan menyatakan bahwa sejumlah variabel adalah substansial dan perubahan lingkungan tidak dapat diprediksi. Oleh karena itu, pilihan strategi yang baik bergantung pada bagaimana menciptakan organisasi perusahaan yang fleksibel. Di samping itu juga mengembangkan sumber daya pembelajar yang kritis dan adaptif terhadap perubahan. Pandangan yang lain menyatakan bahwa sumber keunggulan berasal dari kemampuan membuat pilihan strategi yang baik dan menerapkannya. Satu hal yang penting adalah, bagaimana menghadapi perubahan lingkungan yang cepat dengan menyediakan kesempatan terbuka terhadap pilihan-pilihan yang baru. Tetapi, lagi-lagi menurut Porter, hal tersebut masih menyisakan pertanyaan: mengapa beberapa perusahaan lebih baik daripada yang lain.

Keunggulan kompetitif berasal lingkungan sekitar di mana perusahaan didirikan. Poin awal teori ini adalah bahwa perubahan lingkungan berlangsng terus dan perusahaan, melalui inovasi, memiliki peluang dalam memengaruhi lingkungan. Dengan itu perusahaan dapat menciptakan keunggulan kompetitif secara berkelanjutan. Pembaruan proses melalui rantai nilai (value chain) dengan tipe yang canggih (sophisticated) dan tenaga kerja berketerampilan tinggi serta teknologi. Imperattif keunggulan kompetitif, bagaimanapun, merupakan kecenderungan perusahaan. Di sini kekuatan lingkungan eksternal, dan seringkali esensial, berpengaruh terhadap kecenderungan tersebut. 


\section{Determinants of National Compotitive Advantage (M. E. Porter, 1990, 1991)}

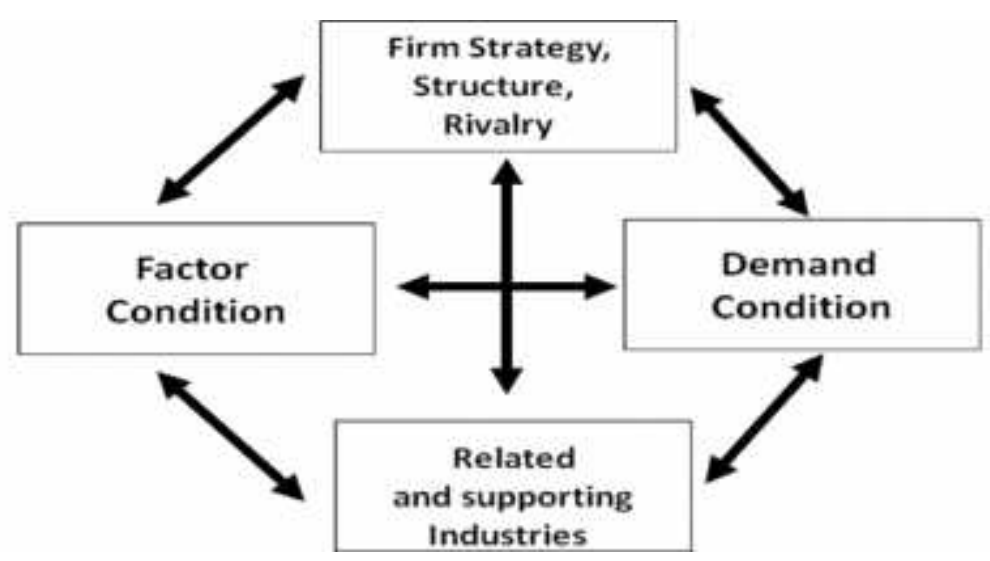

\section{Gambar Diamond}

Gambar (diamond) di atas menunjukkan empat atribut dari lingkungan sekitar dari suatu perusahaan. Lingkungan memiliki pengaruh terbesar dalam melakukan inovasi dan upgrade. Lingkungan sangat penting dalam memahami keunggulan kompetitif. Faktor terpenting produksi adalah spesialisasi yang tinggi, melalui pelatihan yang disesuaikan dengan kebutuhan industri (tailored). Spesialisasi faktor-faktor lokal tersebut mampu mendorong akumulasi secara cepat terhadap keterampilan dan tingkat inovasi terbaik. Adanya mekanisme kelembagaan yang unik, merupakan faktor penentu dalam keberhasilan berkompetisi. Keunggulan kompetitif juga dipengaruhi oleh kekuatan para pemasok (suppliers) dan industri sejenis.

Menurut Porter, penentu keunggulan kompetitif adalah strategi perusahaan, struktur, dan para pesaing. Atau, konteks dalam persaingan tingkat daerah dan nasional. Kehadiran pesaing lokal juga berpengaruh terhadap pengembangan inovasi. Pesaing lokal memiliki rangsangan lebih besar daripada pesaing asing untuk melakukan upgrade. Di samping itu, faktor lingkungan yang turut memengaruhi keunggulan kompetitif adalah pemerintah.

Memahami aturan dan kebijakan pemerintah, menurut Porter, merupakan cara terbaik untuk memahami keunggunalan kompetitif nasional. Sebab, pemerintah berperan 
penting dalam menciptakan tekanan, insentif, dan kemampuan perusahaan nasional. Pemerintah berperan sebagai katalis dan penantang. Pemerintah dapat memotivasi, bahkan mendorong perusahaan untuk bangkit dan bergerak pada level kinerja kompetitif yang tinggi. Pemerintah dapat menciptakan lingkungan, melalui kebijakan, untuk meraih keunggulan kompetitif, langsung maupun tidak langsung.

Aspek lingkungan merupakan dasar dari sistem dinamis. Karakteristik lingkungan adalah sentral pada proses-proses perusahaan untuk meraih keunggulan. Pengaruh yang menentukan bergantung pada keberadaan perusahaan tersebut dihadapkan pada yang lain. Kehadirannya secara canggih dan permintaan para pembeli, sebagai contoh, bukanlah merupakan hasil yang diinginkan. Melainkan terutama adalah bagian dari proses keunggulan yang berkelanjutan.

Bagian lain dari the diamond yang digagas oleh Porter ini, sebagaimana terlihat pada gambar di atas, adalah juga upaya saling menguatkan kembali (mutually reinforcing). Pengembangan industri terspesialisasi, sebagai contoh, cenderung untuk menaikkan penawaran faktor-faktor yang terspesialisasikan tersebut. Para pesaing domestik terdorong untuk melakukan hal yang sama.

Mengutip hasil penelitian Universitas California pada industri lokal, Porter mengemukakan bahwa, Para pesaing lokal juga secara aktif melakukan upgrade permintaan rumah tangga melalui pendidikan pembeli dan penyediaan pilihan, dan formasi promosi industri pendukung. Lingkungan nasional dan lokal untuk bersaing dalam industri tertentu itu sendiri berkembang dalam proses dinamis. Lingkungan dibuat dari waktu ke waktu melalui penguatan yang saling menentukan. Penguatan faktor penentu mencerminkan sebagian tindakan perusahaan dalam membangun lingkungan dari waktu ke waktu.

The Diamond yang dikembangkan oleh Porter, juga membincangkan tentang faktor pergerakan individu yang memiliki gagasan (ide) dan berketerampilan tinggi dalam kompetisi global. Faktor-faktor pergerakan (mobile factors) menggambarkan lokasi di mana mereka dapat mencapai produktivitas terbaik, dan keuntungan/pendapatan yang terbaik pula. Teori diamond Porter ini berfokus pada penentu produktivitas, juga 
menjelaskan daya tarik faktor-faktor pergerakan (mobile) tersebut. Jadi, lingkungan diciptakan melalui usaha saling penguatan kembali (mutual reinforcement) terhadap faktor-faktor yang menentukan.

Untuk menghindari kekaburan konsep diamond tersebut, Porter menyodorkan hasil penelitiannya mengenai pengelompokan industri (clusters) dalam satu lokasi. Menurutnya, cara ini akan meningkatkan keunggulan kompetitif karena akan mendorong industri lain untuk melalukan cara yang sama. Cara pengelompokan industri dalam satu lokasi, akan memuculkan industri pemasok, industri pelanggan, dan industri lainnya untuk berkompetisi. Clusters memiliki karakteristik advanced dalam perekonomian. Misalnya di AS (industri hiburan), Jerman (industri farmasi), Jepang (industri elektronik), dan Indonesia (?)

Porter beralasan bahwa strategi cluster untuk industri akan memudahkan penyediaan tiga sumber daya keunggulan kompetitif perusahaan, yakni: (1) Keuntungan produktivitas (Productivity gains); (2) Kesempatan inovasi (Innovation opportunities); dan (3) Formasi bisnis baru (New business formation). Dengan kata lain, melalui strategi cluster pada industri, produktivitas, inovasi, bisnis baru akan terjadi akibat adanya spesialisasi input dan keterampilan pekerja, akses pada informasi industri khusus dan pengetahuan industri, pengembangan hubungan yang saling menguntungkan di antara perusahaan dan industri, dan bahkan dukungan dari universitas atau lembaga pelatihan yang akan memudahkan transfer pengetahuan dan keterampilan.

Implikasi lain dari teori ini adalah perlunya mempertimbangkan aspek geografis (konsentrasi geografis), khususnya untuk pengembangan wilayah dan perkotaan. Dalam tataran nasional, pengelompokan industri akan menjadi daya tarik interaksi yang menentukan. Poin pentinya adalah, bagaimanapun perusahaan kadang kala dapat gagal bukan disebabkan oleh faktor lingkungan, melainkan terutama oleh faktor internal manajerial yang tidak adaptif terhadap perubahan lingkungan.

Menurut Porter, terdapat lima kekuatan kompetitif yang menentukan kekuatan industri. Kelima kekuatan tersebut adalah: (1) Pemain baru potensial; (2) Pemasok; (3) Pembeli; (4) Substitusi; dan (5) Pesaing dalam industri. Artinya, bagaimana pimpinan 
perusahaan memahami mengenai kelima hal tersebut akan menentukan strategi apa yang harus dipilih. Misalnya, menghadapi ancaman pemain baru, ancaman terhadap produk atau jasa pengganti, dan seterusnya (lihat Porter 1985, 1991). Jadi, sebagaimana tampak pada gambar berikut, lima kekuatan tersebut merupakan cara bagaimana memahami struktur industri.

\section{Understanding Industry Structure}

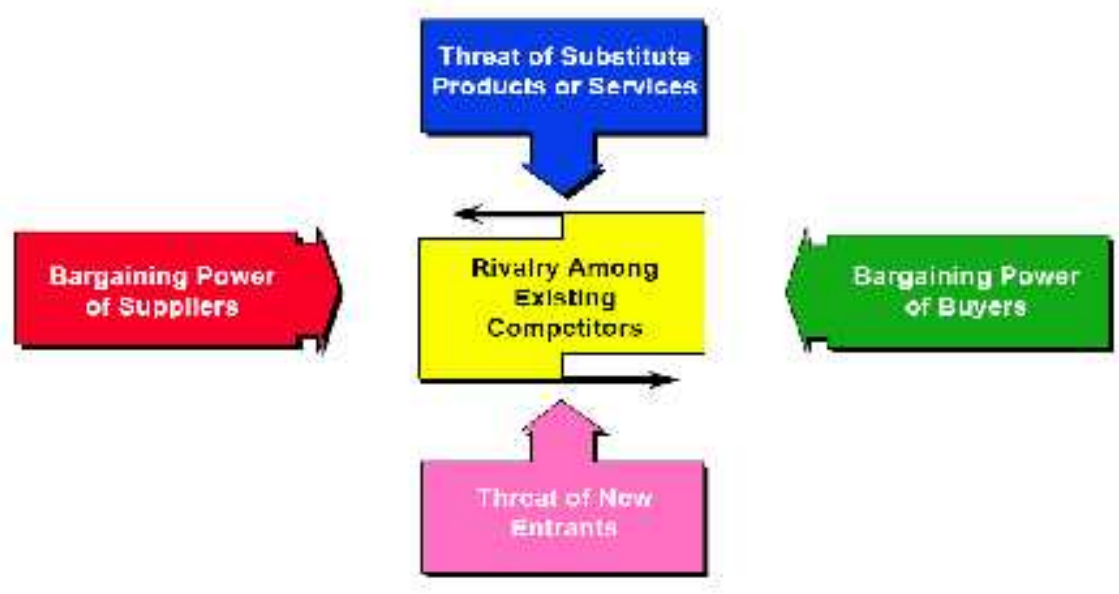

Dalam mengemukakan strategi untuk mencapai keunggulan kompetitif atau daya saing, Porter mengajukan cara ini: deferensiasi dan biaya rendah, yang terkenal dengan strategi generik Porter (Porter, 1985; 1991). Artinya, pada strategi biaya rendah harga jual ke pembeli berada atau mendekati harga rata-rata industri. Produk atau jasa yang dijual dipersepsikan sebagai layak dibandingkan dan bisa diterima. Struktur biaya berarti terendah di antara para pesaing. Pada strategi deferensi produk atau jasa di mata pembeli merupakan hal yang unik dengan harga premium.

Di samping itu, sebagaimana tampak pada gambar berikut, Porter juga menjelaskan pentingnya kerangka kerja rantai nilai (value chain) sebagai fondasi meraih keunggulan kompetitif (Porter, 1985; 1991). Kerangka kerja rantai nilai menggambarkan dua kegiatan, yakni kekiatan utama (primary activities) dan kegiatan yang mendukung kegiatan utama (support activities). Kegiatan utama terdiri dari: logistik masuk, operasi, logistik keluar, pemasaran, dan layanan purna jual. Sedangkan kekiatan pendukung 
kegiatan utama terdiri dari: infranstruktur, manajemen sumber daya manusia, pengembangan teknologi, dan pengadaan (Porter, 1985; 1991).

\section{Foundations of Competitive Advantage The Value Chain}

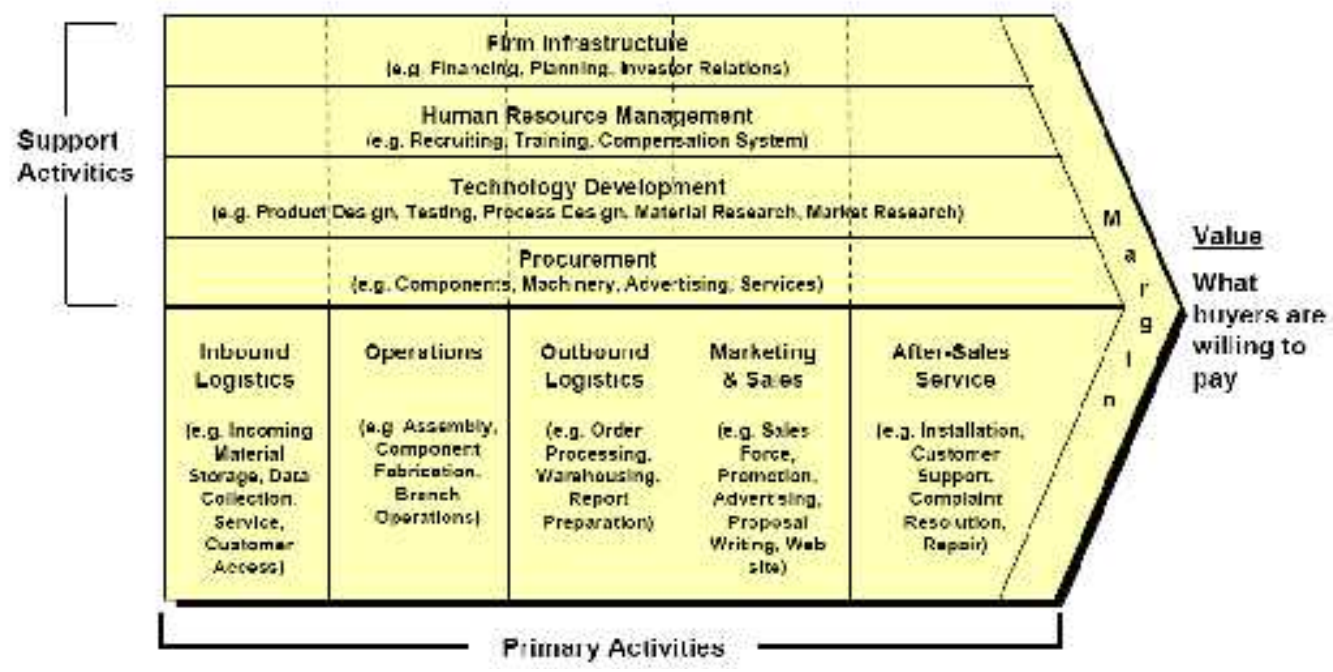

Mengapa beberapa perusahaan mampu melakukan aktivitas dengan biaya rendah atau mampu menciptakan keunggulan nilai daripada perusahaan yang lain? Jawabannya adalah adanya konsep penggerak (the concept of driver). Ia adalah penentu struktural yang membedakan di antara para pesaing, dapat berupa biaya adatu aktivitas (Porter, 1991). Secara demikian, driver merupakan sumber yang mendasari keunggulan kompetitif, dan membuat keunggulan kompetitif dapat beroperasional. Sebagai contoh, reputasi merek merupakan keunggulan kompetitif tipikal diidentifikasi oleh para manajer. Pertanyaanya adalah, mengapa reputasi merek dapat menjadi keunggulan kompetitif? Jawabannya adalah timing yang tepat, misalnya dalam advertensi. Konsep drivers, dapat digunakan pula pada konteks kompetisi global (Porter, 1991).

Dari pemaparan di atas dapat dikemukakan bahwa pemikiran Stratejik Porter, dapat dikategorikan menjadi tiga: (1) Strategi Generik (SG); Strategi Cluster (SC); Strategi Dinamik (SD). Pada Strategi Generik, Porter menjelaskab 4 hal ini: kepemimpinan biaya, deferensiasi, fokus pada biaya, dan fokus pada deferensiasi sebagai basis pilihan perusahaan. Berdasarkan model tersebut, maka perusahaan dapat memilih 
bagaimana kemampuan yang diinginkan, didasarkan pada perpaduan antara bentukbentuk dan target pasar sebagai kunci pilihan tersebut.

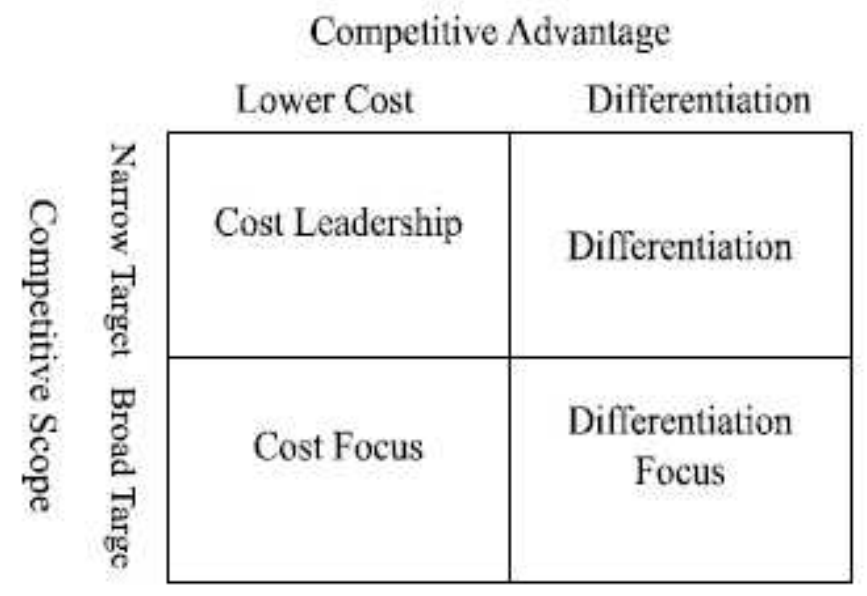

Pada Strategi Cluster, Porter menjelaskan pentinya melakukan pengelompokan industri untuk memahami konsep diamond. Porter menyodorkan hasil penelitiannya mengenai pengelompokan industri (clusters) dalam satu lokasi. Menurutnya, cara ini akan meningkatkan keunggulan kompetitif karena akan mendorong industri lain untuk melalukan cara yang sama. Cara pengelompokan industri dalam satu lokasi, akan memuculkan industri pemasok, industri pelanggan, dan industri lainnya untuk berkompetisi. Clusters memiliki karakteristik advanced dalam perekonomian.

Sedangkan pemikiran Porter mengenai dynamic theory of strategy dikembangkan berdasarkan urutan ini: (1) pendekatan bangunan teori (model dan framework); (2) penentu sukses dalam bisnis (the determinants of success in distict business); (3) lima kunci kekuatan yang menggerakan (five forces: summary of key drives); (4) kerangka kerja rantai nilai dan sistem (value chain \& value system); dan (5) penentu keunggulan kompetitif nasional (determinants of national competitive advantage).

Secara demikian, maka pemikiran stratejik Porter dapat dirangkum dalam istilah Strategi Dinamik yang intinya adalah sebagai berikut: 
1. Basis teori dinamika strategi yang dikembangkan Porter terletak pada gambar the diamond. Intinya adalah bagaimana membangun kembali kesaling kekuatan (mutually reinforcement) dan rantai kausalitas (chain causality).

2. Porter mengklaim bahwa pendekatan teorinya tersebut (dynamic theory), merupakan pendekatan yang baru, berbeda dengan teori yang ia kritik sebelumnya. Menurut Porter, teori sebelumnya mengandaikan lingkungan yang stabil. Padahal lingkungan bisnis terus berubah.

3. Sumbangan pemikiran Porter mengenai teori stategi terutama terletak pada perspektif lingkungan perusahaan (lokal, nasional, dan global) yang terus berubah. Dan, pentingnya meraih keunggulan kompetitif berkelanjutan. Caranya adalah dengan strategi biaya yang rendah, deferensiasi, dan fokus pada bidang industri yang menarik dan paling dikuasai.

\section{Pengertian Industri Kreatif}

Departemen Kebudayaan, Media, dan Olah Raga (DCMS) pemerintah Inggris memetakan industri kreatif ke dalam 13 sub-sektor, yakni: Periklanan, Arsitektur, Seni dan Pasar Barang Antik, Kerajinan Tangan, Desain, Fesyen, Software Hiburan Interaktif, Film dan Video, Musik, Seni Pertunjukan, Penerbitan, Software Layanan Komputer, TV dan Radio. DCMS mendefinisikan industri kreatif sebagai sektor industri di mana kreativitas, keterampilan, dan bakat individu merupakan potensi untuk mengembangkan kesejahteraan atau kekayaan dan kreasi kerja melalui antargenerasi dan kekayaan intelektual (DCMS, 1998).

Menurut konferensi PBB untuk perdagangan dan pembangunan (UNCTAD), secara global industri kreatif diprediksi mampu menyumbang GDP dunia lebih dari $7 \%$ dengan nilai pertumbuhan rata-rata $10 \%$ per tahun. Lembaga PBB ini juga mengemukakan bahwa kreativitas lebih dari sekedar pekerja dan kapital bahkan teknologi, melainkan terutama merupakan kultur atau kebudayaan yang telah membumi pada setiap negara. Pengembangan sumber-sumber kreativitas tersebut menjadi peluang dalam meningkatkan kesejahteraan negara-negara berkembang (UNCTAD, 2004). 
Innovation performance at the regional level: creative industries and other sectors - 2004-2006

\begin{tabular}{|c|c|c|c|c|c|c|c|c|c|}
\hline Reglon & $\frac{\frac{7}{2}}{\frac{3}{2}}$ & 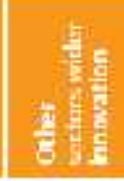 & 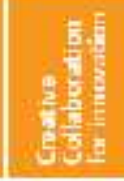 & 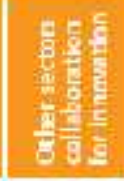 & 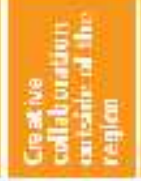 & 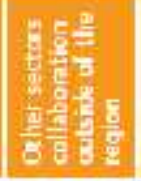 & 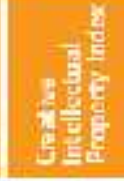 & 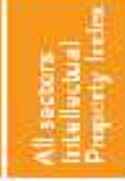 & $\frac{5}{\frac{5}{5}} \frac{5}{6}$ \\
\hline Noth Eest & $64 \%$ & $20 \%$ & $23 x$ & $10 \%$ & $83 \%$ & $78 \% 6$ & $E 1 \%$ & $35 \%$ & 73 \\
\hline Noth Wast & $43 \%$ & $29 \%$ & $10 \%$ & $11 \%$ & $\mathrm{~N} \Delta^{+}$ & 7436 & 615 & $\angle A \% 6$ & $3 \%$ \\
\hline rorks \& HuT:a- & $50 \%$ & $28 \%$ & $12 \%$ & $11 \%$ & $\mathrm{NA}$ & E55 & $53 \%$ & $10 \%$ & $5 \%$ \\
\hline Firl Minllires. & $44 \%$ & $29 \%$ & $x \%$ & $13 \%$ & $73 \%$ & $85 \%$ & $49 \%$ & $\triangle 4 \%$ & $7 \%$ \\
\hline 'Wer-Micancs & $51 \%$ & $27 \%$ & $14 \%$ & $12 \%$ & $76 \%$ & $80 \%$ & $59 \%$ & $45 \%$ & $4 \%$ \\
\hline East & $46 \%$ & $34 \%$ & $22 \%$ & $13 \%$ & $86 \%$ & 5026 & $7 \%$ & 4706 & $11 \%$ \\
\hline Londor & $76 \%$ & $39 \%$ & $7 \%$ & $10 \%$ & $60 \%$ & $68 \%$ & $50 \%$ & 4376 & $15 \%$ \\
\hline soutt sast & $32 \%$ & $36 \%$ & $7 \%$ & $12 \%$ & b\% & $81 \%$ & $66 \%$ & 4170 & 136 \\
\hline Sxuth Wort & $42 \%$ & $30 \%$ & $75 \%$ & $11 \%$ & $70 \%$ & $80 \%$ & $59 \%$ & $41 \%$ & $7 \%$ \\
\hline Wale; & $5 \%$ & $26 \%$ & $74 \%$ & $c \%$ & NA' & $78 \%$ & $=8 \%$ & $41 \%$ & $B ;$ \\
\hline 5scolland & $15 \%$ & $28 \%$ & $75 \%$ & 98 & $62 \%$ & 6038 & $59 \%$ & $35 \%$ & $10 \%$ \\
\hline Average & $16 \%$ & $30 \%$ & $16 \%$ & $11 \%$ & $79 \%$ & $79 \%$ & $9 \%$ & $42 \%$ & $9 \%$ \\
\hline
\end{tabular}

Sumber: Chapain at al., Creative clusters and innovation (2010).

Industri kreatif merupakan bagian dari ilmu budaya atau cultural sciencel kulturewissenschaft (Potts (2008). Kreativitas berhubungan dengan kepemimpinan manajerial, atensi, dan motivasi (Powell, 2008). Dengan kata lain, untuk mengembangakan kreativitas pekerja dalam organisasi diperlukan kepemimpinan yang peduli dan perhatian terhadap hubungan klien dengan perusahaan (Powell dan Dodd. 2007). Di sisi lain kreativitas berhubungan pula dengan loyalitas (Jin-bing et al, 2009).

Kecenderungan industri kreatif semakin mengglobal diindikasikan oleh meningkatnya investasi, produk, dan brand yang unik (Millar et al, 2005). Industri kreatif adalah bagian dari ekonomi berbasis pengetahuan (the knowledge-based economy) berdasarkan inovasi atau R\&D (Cunningham, 2004). Berbeda dengan creative commons, kreatif industri terkait dengan dimensi legal, terutama copyright dan intellectual property law (Flew, 2005). 
New York City's Creative Economy, Total Workers, 2002

\begin{tabular}{|c|c|c|c|c|}
\hline Indietio: & Inserinting: & $\begin{array}{l}\text { Peaple Worting } \\
\text { Within Fins with } \\
\text { Fmplowers }\end{array}$ & Soln:Pinoulatore: & Intal \\
\hline Fublisting & Hens: os: beck, ncm:paser puo iehers & AS.:2 & 2,191 & 02.870 \\
\hline Iim and Vides & 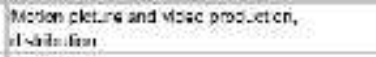 & $11=2=7$ & 9.791 & $-r_{1}-48$ \\
\hline Muslo Produottan & 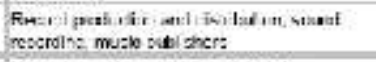 & $0,2 \times 0$ & $x a$ & $0,8 \pi 7$ \\
\hline Brondosztian. & 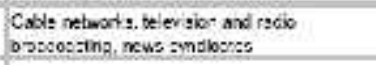 & $a r: 02$ & o. & 37,002 \\
\hline Rrabickstire & Weonteos.re. lecossape archisetur sevioce & 10.28 & 2ust & -3.32 \\
\hline ropliod v zugn & Spesu zod des gn, crotortsch: ecrio:s & 14,112 & 13,$8 ;-1$ & 2, ien \\
\hline filvaliuing & 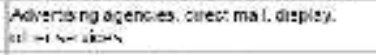 & $83,17:$ & 4.74 & 97900 \\
\hline Partorming ars & $\begin{array}{l}\text { i hever. derce settom no s7s vamps-ies } \\
\text { anc muaka grouss }\end{array}$ & 22,347 & $1,7.4$ & $2-6,811$ \\
\hline$Y_{n=1} d A_{1}=$ & 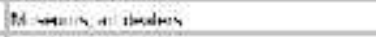 & $Q: R=9$ & 1.19 & $\cdots, 124$ \\
\hline Other & 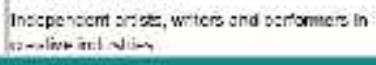 & $3.3: 7$ & $4 \cap 8,4$ & $m, 18$ : \\
\hline \multicolumn{2}{|c|}{ 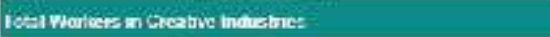 } & nas, sil & mist & 20,258 \\
\hline
\end{tabular}

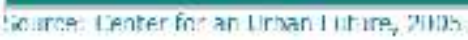

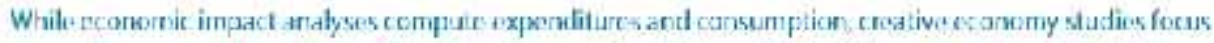

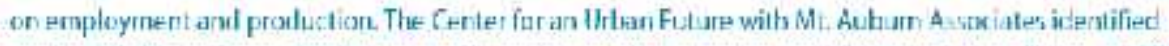
nearly 280,000 workers-200,000 nonprolit and lor-profit employees ard 30,000 sole proprietoss-in NYCb

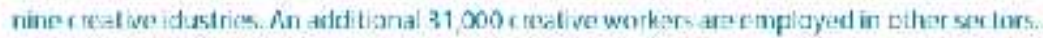

Kecenderungan industri kreatif semakin mengglobal diindikasikan oleh meningkatnya investasi, produk, dan brand yang unik (Millar et al, 2005). Industri kreatif adalah bagian dari ekonomi berbasis pengetahuan (the knowledge-based economy) berdasarkan inovasi atau R\&D (Cunningham, 2004). Berbeda dengan creative commons, kreatif industri terkait dengan dimensi legal, terutama copyright dan intellectual property law (Flew, 2005).

Oleh karena industri kreatif tidak dapat dilepaskan dari konteks sosial, ekonomi, dan politik (Shorthose, 2004). Maka, strategi dan kebijakan pemerintah untuk mengembangkan industri kreatif, harus berfokus pada dimensi sumber daya manusia (human capital). Program yang harus dilakukan adalah fokus pada pengembangan bisnis, manajemen, dan dukungan keterampilan terutama yang berpotensi ekspor (Higgs dan Cunningham, 2008).

Literatur pemasaran telah memasukkan kasus perusahaan terutama tentang bagaimana mereka mendemonstrasikan model inovasi bisnis yang dihasilkan, demi meraih keuntungan yang berkelanjutan dan keunggulan kinerja jangka panjang. Intinya 
adalah bagaimana perusahaan melakukan---dalam istilah Schumpeter---“creative destruction", dan itu adalah domain entrepreneurship, kewirausahaan (Schindebutte, et al, 2008). Perlu dikemukakan di sini bahwa tidak semua kreativitas berorientasi pada kesuksesan finansial, karena terdapat pula kreativitas, terutama pada industri kreatif bersakala kecil, lebih diorientasikan untuk ekpresi diri dan keseimbangan hidup/kerja (Chaston, 2008).

Pengembangan kreativitas dalam industri, sebagaimana terjadi dalam perkembangan jaringan internet, berhubungan dengan kebijakan pemberian subsidi (Lee dan $\mathrm{Wu}, 2009)$. Sebagaimana industri perfilman di India, mereka tidak hanya mendapat dukungan dari perusahaan tetapi juga diuntungkan oleh kuatnya nilai-nilai nasionalisme (Hassam, 2009). Jika dilakukan pembinaan secara efektif, industri kreatif pada negaranegara berkembang, dapat mendorong pertumbuhan ekonomi dan pembangunan (UNCT, 2004).

Aktivitas kreatif berkorelasi secara alamiah dengan output (Chaston, 2008). konsistensi dan koherensi antara elemen-elemen identitas perusahaan (missal: corporate culture, corporate design, corporate communication and corporate behavior) merupakan masalah krusial dalam mengembangkan citra perusahaan (Vallaster dan Chernatony, 2006).

Strategi pemasaran dalam industri kreatif berhubungan dengan alokasi pekerja berbakat dan berpengetahuan (knowledge workers) atau individu kreatif. Faktor-faktor yang memengaruhi perusahaan memengaruhi pula pengembangan karakter individu kreatif. Faktor-faktor tersebut adalah: politik, potensi pasar, landasan ekonomi, kebudayaan, dan aturan hukum. Di samping itu, lingkungan internal perusahaan seperti orientasi pasar, budaya perusahaan, struktur perusahaan, dan lingkungan lokal juga berpengaruh (Pitta et al, 2008). 


\section{Hasil Temuan Empiris}

Untuk Strategi Generik Porter, penelitian Bodean at al (2010), yang menguji tentang penggunaan stategi generik pada industri perhotelan di Rumania menemukan bahwa: Pertama, sebagaimana ditunjukkan oleh berikut (Tabel 1), strategi deferensiasi dan stategi fokus pada deferensiasi merepresentasikan strategi generik Porter. Sedangkan kepemimpinan biaya dan fokus pada strategi biaya tidak menggambarkan strategi generik Porter. Artinya, pada industri perhotelan di Rumania, strategi generik Porter hanya tergambarkan oleh dua hal tersebut.

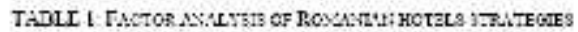

\begin{tabular}{|c|c|c|c|c|}
\hline Sirategir prativen. & $\begin{array}{l}\text { Diffulutiation } \\
\text { strategys }\end{array}$ & $\begin{array}{c}\text { Facus diffowitiations } \\
\text { stanes: }\end{array}$ & $\begin{array}{l}\text { Trauing } \\
\text { trmergets }\end{array}$ & $\begin{array}{c}\text { Hirbidi } \\
\text { thatregrts }\end{array}$ \\
\hline 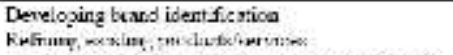 & $\begin{array}{l}0,699 \\
\text { Dyin }\end{array}$ & & & \\
\hline 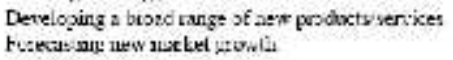 & 0,747 & & & \\
\hline Toxsaring =xirting warse: gronth & 0,526 & & & \\
\hline 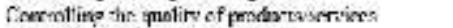 & $0 ; 74$ & & & \\
\hline Loporing operztisual eff-seacy & 0,661 & & & \\
\hline Parturring with amppliser= & 0,310 & & & \\
\hline Uhilizing a dvertisiug & 0,699 & & & \\
\hline 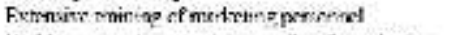 & $\Delta E t^{2}$ & & & \\
\hline 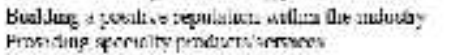 & & $\begin{array}{l}0.817 \\
1.814\end{array}$ & & \\
\hline 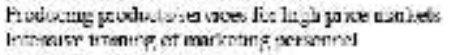 & & $\begin{array}{l}\text { 0.61I } \\
1,7 x K\end{array}$ & & \\
\hline 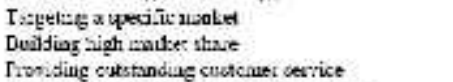 & & 0,723 & & \\
\hline 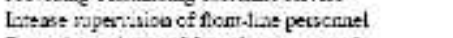 & & & 6452 & \\
\hline Ixtensive tainag of ficut Lat percicial & & & 0,728 & \\
\hline Exrensive rniniag of badk-lies personed & & & 0.245 & \\
\hline 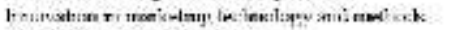 & & & 1. $8 \times 1$ & \\
\hline Dremirg urgrminat - diens: & & & 6823 & \\
\hline \multirow[t]{3}{*}{ 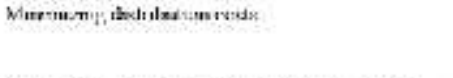 } & & & & 40,0 \\
\hline & & & & 865 \\
\hline & & & & $\mathrm{V}, 1,1$ \\
\hline
\end{tabular}

Kedua, hasil ANOVA mengindikasikan praktik strategi signifikan untuk setiap empat strategi generik (Tabel 2), dan mampu menjelaskan $91 \%\left(\mathrm{r}^{2}=0.914\right.$ untuk strategi deferensiasi), $60 \%\left(\mathrm{r}^{2}=0.605\right.$ untuk strategi hibrid). Jadi, hasil penelitian tersebut menunjukkan bahwa strategi generik Porter signifikan dengan praktik pada industri perhotelan di Rumania (Sig. < 0.05). Signifikansi praktik strategi industri perhotelan di Rumania dengan strategi generik Porter tersebut, termasuk pada spesialisasi produk dan jasa, reputasi bangunan pada industri, harga pasar dan training. 


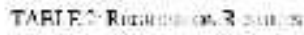

\begin{tabular}{|c|c|c|c|}
\hline Differeetiation strat:gy & Iocus differtatiation strategy & Training strstegy & IIyòrid strategr \\
\hline 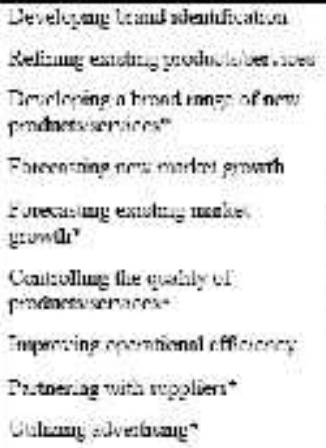 & 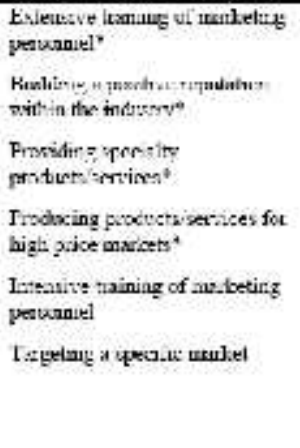 & 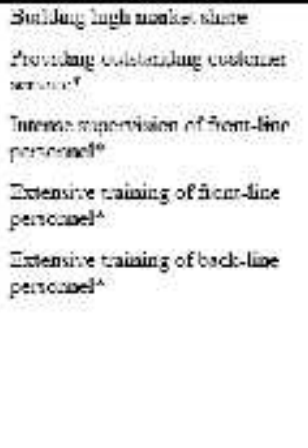 & 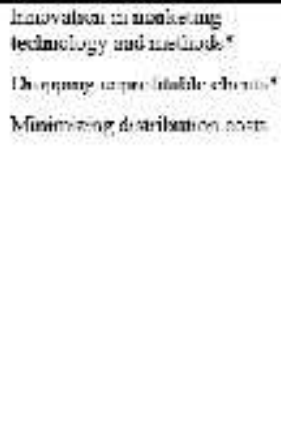 \\
\hline
\end{tabular}

Berikut adalah hasil temuan Suleyman (2008) dalam menganalisis industri di Turki berdasarkan lima kekuatan kompetitif Porter. Peneliti ini, dengan mengadopsi pemikiran stratejik Porter tersebut, mengemukakan kerangka analisisnya sebagai berikut:

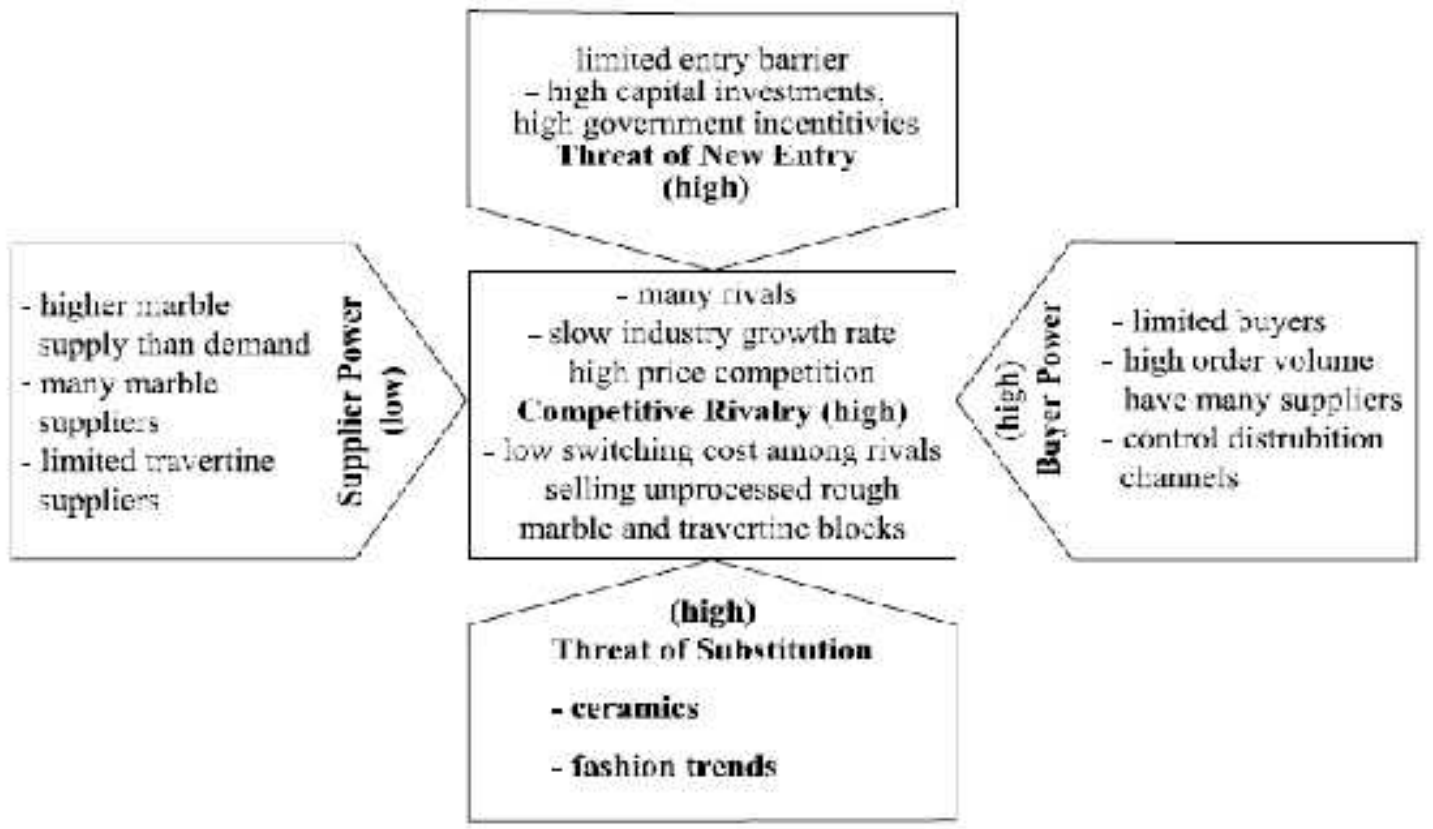

Dewasa ini, Turki seharusnya memiliki keunggulan kompetitif tinggi di bidang industri marble dan travertine dari Itali, China,dan beberapa negara lain. Tetapi, berdasarkan kerangka pemikiran di atas, hasil temuan peneliti ini menyimpulkan bahwa industri tersebut tidak menguntungkan bagi rakyat Turki. Seharusnya, menurut Suleyman, seluruh proses pengolahan sumber daya alam dari Turki diekspor dengan 
nama merek dagang Turki. Sehingga Turki tidak hanya mengekspor bahan mentah saja. Akibatnya, keunggulan kompetitif, sebagaimana Porter kemukakan, tidak tercapai oleh industri tersebut. Dengan kata lain, meskipun Turki memiliki sumber daya alam, negara tersebut tidak mampu memperoleh keunggulan kompetitif. Pendeknya, Turki hanya didekte oleh industri Asing.

Dengan demikian, maka keunggulan kompetitif diraih oleh perusahaan Italia dan China karena mereka mampu menerapkan lima kekuatan Porter. Italia menggunakan strategi deferensiasi, dan China menggunakan strategi kepemimpinan harga pada industri tersebut. Akibatnya, produk China lebih murah. Peneliti ini menyarankan, seharusnya Turki menerapkan strategi deferensiasi dan fokus pada deferensiasi.

Untuk strategi cluster, kajian Keane (2009) mengenai industri kreatif di China menemukan bahwa strategi tersebut merupakan eksperimen menarik bagi kalangan akademisi. China mampu beradaptasi dalam ekonomi global, terutama pada industri kreatif (film, seni, fesyen, dan media). Kuncinya adalah terletak pada kontrak sosial antara pemerintah (lokal), pengusaha, artis, pekerja kreatif, dan universitas dalam membuat cluster industri.

Hasil kajian Porter dan Sakakibara (2004), mengenai keunggulan kompetitif industri di Jepang, mampu menjelaskan mengapa beberapa perusahaan Jelang dapat berinovasi dan sukses dalam pasar ekspor. Kuncinya adalah fokus pada kepemimpinan biaya melalui TQM. Di samping itu juga adanya peran pemerintah dalam membuat aturan, meskipun harus diakui, kadang kala pada kebijakan protektif dapat menimbulkan distorsi.

Kajian di perkotaan Belanda menunjukkan bahwa jaringan industri kreatif di kawasan perkotaan lebih inovartif daripada di kawasan pedesaan (Stam et al, 2008). Sedangkan kajian di Inggris, pada kawasan perkotaan tidak otomatis menjadikan wilayah kreatif, bergantung pada tata ruang dan peruntukan kota tersebut (Jayne, 2004). Tetapi yang jelas strategi pengembangan kota, dengan menata kluster kreatif misalmnya, dapat menumbuhkan daya saing dan perkembangan industri kreatif karena mereka dapat saling 
belajar dan mempromosikan serta memasarkan produk dan jasanya secara bersama (Bagwell, 2008).

Berdasarkan pengujian model yang dilakukan oleh Pott dan Cunningham, menunjukkan bahwa: (1) industri kreatif merupakan sektor khusus yang berpengaruh dalam perkembangan ekonomi; (2) industri kreatif merupakan bagian dari sistem inovasi. Menurutnya, perkembangan relatif dari industri kreatif bukan satu keganjilan, tapi akan membuka teori sistem ekonomi. Sebagaimana pertumbuhan ekonomi akibat dari adanya kemajuan teknologi, Bukti survei menunjukkan bahwa perkembangan industri kreatif merupakan evolusi yang mengarahkan preekonomian (Potts dan Cunningham, 2008).

\section{Implikasi Pemikiran Stratejik Porter}

Berdasarkan pemikiran teoretis dan kajian empiris tentang pemikiran stratejik Porter, sebagaimana telah dikemukakan di atas, maka dapat ditarik implikasinya sebagai berikut:

Pertama, bagi para pimpinan perusahaan. Pemikiran stratejik Porter mengandaikan kemampuan para pimpinan perusahaan dalam memahami struktur industri. Hal tersebut berarti diperlukan kemampuan mengakeses dan mengolah informasi yang akurat dan relevan dengan bisnis utama perusahaan. Bagi mereka yang sedang membangun business start up di sektor ekonomi kreatif, resep stratejik Porter yang sudah teruji tersebut dapat diadaptasi. Kreativitas kaum mileneal Indonesia tidak kalah dengan mereka yang tinggal di negara-negara maju. Porter telah memberi peta jalan, apalagi dengan kemamouan teknologi informasi kaum muda, niscaya akan terwujud keunggulan ekonomin kreatif Indonesia.

Kedua, bagi para akademisi. Tawaran Porter mengenai dynamic theory of strategy membuka peluang untuk penelitian lebih lanjut, mengingat lingkungan bisnis yang senantiasa dinamis. Misalnya munculnya konsep wikinomic belakangan ini telah menggugat kalangan akademisi. Konsep wikinomic telah memengaruhi struktur, perilaku, dan pada akhirnya adalah strategi. Pemikiran stratejik Porter dapat diadaptasi oleh 
kalangan akademisi, terutama untuk bagi perguruan tinggi yang sudah siap menuju entrepreneurial university.

Ketiga, bagi pemerintah. Implikasinya adalah bahwa pemerintah harus membuat kebijakan yang pro pada terciptanya keunggulan kompetitif. Gagasan pemerintah tentang percepatan pembangunan ekonomi nasional misalnya, yang menjadi concern pemerintahan sejak Presiden Yudhoyono, dapat dianalisis dengan menggunakan pemikiran stratejik Porter di atas.

Caranya adalah, pemerintah harus terbuka dan bersedia bekerja sama dengan seluruh stakeholders bangsa ini. Misalnya tentang bagaimana menghadapi fenomena biaya ekonomi tinggi (high cost economy), yang sudah barang tentu tidak akan kompetitif bagi industri nasional. Jika persoalan ini tidak kunjung teratasi, maka pemikiran stratejik Porter (strategi generik): kepemimpinan biaya, fokus pada biaya sulit dilakukan. Karena ada masalah struktural. Pemerintah bersama industri dan universitas juga dapat memperkokoh model triple helix untuk pengembangan kewirausahaan dan inovasi .

Apalagi dengan tingkat korupsi yang semakin mencemaskan yang dilakukan oleh sebagain pejabat pemerintah yang seharusnya bertanggung jawab terhadap jalannya pembangunan, apa yang dikemukakan Porter tentang strategi bersaing dan pengklasteran industri hanya akan menjadi retorika. Padahal potensi industri kreatif untuk berkembang dan bahkan akan mampu bersaing di tingkat global sangat luar biasa.

Jadi, diperlukan kebijakan yang mampu menciptakan lingkungan bisnis yang kompetitif. Apalagi terhadap pemikiran stratejik Porter tentang cluster industies. Tanpa peran pemerintah pengklasteran industri tidak akan pernah terwujud. Apalagi proyek semacam ini membutukan, tidak hanya konsistensi kebijakan pemerintah, melainkan terutama adalah pendekatan interdisipliner yang masih belum berkembang dalam dunia akademik kita. Bahkan, dalam dunia akademik, cenderung terjadi spesialisasi yang terkesan dipaksakan. Di mana latar belakang linearitas studi seseorang menjadi ukuran kompetensi. Padahal solusi terhadap kompleksitas masalah pembangunan oleh sebuah disiplin ilmu tidak akan pernah mencukupi. Diperlukan kerja sama dan sikap rendah hati serta dialog antardisiplin ilmu, apalagi menyangkut masalah strategi. 


\section{Kesimpulan}

1. Pemikiran stratejik Porter tentang lima kekuatan kompetitif relevan dengan internasionalisasi dan inovasi industri, sebagaimana telah ditunjukkan oleh penjelasan teori dan penelitian empiris (kasus industri di China)

2. Pemikiran stratejik Porter mengenai lima kekuatan kompetitif tersebut merupakan dasar untuk memahami struktur industri. Hasil penelitian (kasus industri di Turki) menunjukkan bahwa negara tersebut gagal meraih keunggulan kompetitif, padahal negara tersebut memiliki sumber daya alam, akibat tidak memahami struktur industri dan strategi generik Porter.

3. Pemikiran stratejik Porter tentang pentingnya rantai nilai (the value chain), relevan bagi operasi organisasi sebagai basis meraih keunggulan kompetitif, sebagaimana telah ditunjukkan oleh penelitian empiris (kasus industri di China dan Jepang).

4. Pengembangan inovasi cluster industri relevan untuk pembuatan strategi dan kebijakan dalam lingkungan yang dinamis di mana belajar dan jaringan kerja dapat dikembangkan untuk keunggulan kompetitif. Di samping itu, untuk kepentingan industri nasional, pengelompokan (clusters) industri, sebagaimana terjadi di AS, Jerman, dan Jepang, menurut Porter, akan menumbuhkan daya kompetitif secara menyeluruh, sebagaimana dijelaskan melalui bagan/gambar the diamond-nya. Disinilah, kata Porter, peran dan kebijakan pemerintah turut menentukan.

5. Pemikiran stratejik Porter dapat digunakan untuk pengembangan keunggulan kompetitif pada industri kreatif, sebagaimana telah dilakukan di Inggis, Belanda, dan China. Melalui cluster industri, industri tersebut menjadi berkembang dan mampu memengaruhi perekonomian nasional, bahkan di pasar global. 


\section{Daftar Pustaka}

Bagwell, Susan 2008. Creative clusters and city growth. Creative Industries Journal 1 (1): 31-46.

Barutcu, Suleyman. 2008. Porter's five forces analysis for natural stone industry and competitive strategies. Journal of Global Strategic Management 03: 58-67.

Bordean, Ovidiu N., AncaI. Borza, Razvan L. Nistor, dan Catalina S. Mitra. 2010. The use of Michael Porter's generic strategies in the Strategies in the Romanian Hotel Industry. International Journal of Trade, Economics and Finance 1 (2): 173-178.

Chapain, Caroline at al. 2010. Creative clusters and innovation: Putting creativity on the map. NESTA, Laporan Riset (November).

Chaston, Ian. 2008. Small creative industry firm: A development dilemma? Management Decision 46 (10): 819-831.

Cunningham, Stuart. 2002. From cultural to creative industries: Theory, industry, and policy implication. Quarterly Journal of Media Research and Resources 102.

Cunningham, Stuart. 2004. The creative industries after cultural policy: A geneology and some possible prefered futures. International Journal of Cultural Studies 7 (1): 105-115.

DCMS. 1998. Creative Industries Mapping Document. London, UK: HMSO.

Flew, Terry. 2005. Creative commons and the creative industries. Media and Art Law Review 10 (4).

Foord, Jo. 2008. Strategies for creative industries: an international review. Creative Industries Journal Volume 1 (2): 91-113.

Higgs, P., dan S. Cunningham. 2008. Creative industries mapping: Where have we come from and where are we going? Creative Industries Journal 1 (1): 7-30. 
Jayne, Mark. 2004. Culture that works? Creative industries development in a workingclass city. Capital \& Class 84: 199-210.

Jin-bing, Li., Han Yu-qi, Zhu Jian-jun. 2009. Research on Staff Loyalty of Creatives Industries Enterprise from the Perspective of Stakeholder Management Science and Engineering 3 (2): 16-22.

Keane, Michael. 2009. Great adaptations: China's creative clusters and the new social Contract. Journal of Media \& Cultural Studies 23 (2): 221-230.

Keane, M., and Christina Spurgeon. 2004. Advertising industry and culture in post-WTO China Media International Australia 111 (May): 104-117.

Lee, Robin S., and Tim Wu. 2009. Subsidizing creativity through network design: zeropricing and net neutrality. Journal of Economic Prespective 23 (3): 61-76.

Millar, Carla CJM., Chong Ju Choi, and Stephen Chen, 2005. Globalization rediscovered: The case of uniquenness and creative industries. Management International Review 45 (1): 121-128.

Miller, A., dan Dess, G.G. 1993. Assessing Porter,s (1980) model in term of its generalizability, accuracy and simplicity. Journal of Management Studies 30 (4): 0022-2380.

NCTAD. 2004. Creative Industries and Development, Sao Paolo: Eleventh session.

Pitta, D.A., V.R. Wood, dan Frank J.F. 2008. Nurturing an effective creative culture within a marketing organization. Journal of Consumer Marketing 25 (3): 137148.

Porter, Michael E. 1979. The Structure within Industries and Companies' Performance. The Review of Economics and Statistics 61 (2): 214-227.

Porter, Michael E. 1981. The contribution of industrial organization to strategic management. Academy of Management Review 6 (4): 609-20

Porter, Michael E. 1991. Towards a dynamic theory of strategy. Strategic Management Journal 12: 95-117. 
Porter, Michael E. 1996. What is strategy? Harvard Business Review 96 (6) NovemberDecember: 61-78.

Porter, Michael E. 1998. Clusters and the new economics of competition. Harvard Business Review 76: 77-91.

Porter, Michael E. 2000. Location, competition and economic development: local clusters in a global economy. Economic Development Quarterly (14): 15-34.

Porter, Michael E., dan Claas van der Linde. 1991. Towards a new conception of the environment-competitiveness relationhip. Journal of Economic Perspectives 9 (4): 97-118.

Porter, Michael E., dan Mariko Sakakibara. 2004. Competition in Japan. Journal of Economic Perspectives 18 (1-Winter): 27-50.

Potts, J., dan S.D. Cunningham. 2008. Four models of the creative industries. International Journal of Cultural Policy 14 (4): 233-247.

Potts, J., Stuart Cunningham, John Hartley, dan Paul Ormered. 2008. Social network market: A new definition of the creative industries. Journal of Cultural Economics 32.

Potts, Jason. 2008. Creative industries \& cultural science: A definitional odyssey. Cultural Science 1 (1).

Powell, S. dan Chris Dodd. 2007. Managing vision and the brand within the creative industries. Corporate Communications: An International Journal 12 (4): 394413.

Powell, Shaun. 2008. The management and consumtion of organisational creativity. Journal of Consumer Marketing 25 (3): 158-166.

Rossiter, Ned. 2004. Creative industries, comparative media theory and limits of critique from within. Canadian Journal of Cultural Studies 11 (Spring). 
Schindebutte, M., M.H. Morris, dan Akin Kocak. 2008. Understanding market-driving behavior: The role of entrpreneurship. Journal of Small Business Management 46 (1): 4-26.

Shorthose, Jim. 2004. A more critical view of the creative industries: Production, consumption, and resistance. Capital \& Class 84 (Winter): 1-9.

Stam, E., Jeroen PJ de Jong, and Gerard Marlet. 2008. Creative industries in the Netherlands: Structure, development, innovativeness and effects on urban growth. Geografiska Annaler: Series B, Human Geography 90 (2): 119-132.

United Nations Conferenceon Trade and Development (UNCTD). 2004. Creative Industries and Development. Sao Paulo, Brazil: UNCTD.

Vallaster, C., dan Leslie de Chernatony. 2006. Internal brand building and structuration: the role of leadership. European Journal of Marketing 40 (7/8): 761-784.

Zeleny, Milan. 2010. Strategy as action: from Porter to Anti-Porter. International Journal of Strategic Decision Sciences 1 (1). 
Nuryadi Wijiharjono: Pemikiran Michael Porter 